\title{
Recent advances in utilization of flaxseed as potential source for value addition
}

\author{
Parvinder Kaur ${ }^{1}$, Roji Waghmare ${ }^{2}$, Vikas Kumar ${ }^{1}$, Prasad Rasane ${ }^{1}$, Sawinder Kaur ${ }^{1}$ and Yogesh Gat ${ }^{1, *}$ \\ ${ }^{1}$ Department of Food Technology and Nutrition, Lovely Professional University, Jalandhar 144411, India \\ ${ }^{2}$ School of Biotechnology and Bioinformatics, D. Y. Patil University, Navi Mumbai 400614, India
}

Received 25 September 2017 - Accepted 7 March 2018

\begin{abstract}
Flax seed (Linum usitatissimum) is an important oilseed crop which has gained importance since last few decades due to its unique nutrient profile. Flax seed comprises high amount of fiber and is a significant source of $\alpha$-linolenic acid in the diet of vegetarian people. It is evident from several studies conducted that flaxseed carries functional ingredients and provide health benefits. Omega-3 fatty acid, lignan and dietary fiber are major bioactive components of flaxseed which can be delivered through value added products. Flax seed has been successfully exploited in preparation of various value added products. Commercially, all parts of flaxseed plant are exploited directly or after processing. Flaxseed consumption in the diet prevents serious diseases like coronary diseases, cancer, diabetes, obesity, gastrointestinal, renal and bone disorders. To the best of our knowledge, very limited review reports are available for commercial utilization of flaxseed in preparation of various value added products (bakery, dairy, extruded, snack, fermented and other traditional) and effect of flaxseed fortification on nutritional, physicochemical, phytochemical and sensory properties of these products. In future, this data could be useful for different food processing industries.
\end{abstract}

Keywords: flaxseed / health benefits / functional food / nutraceutical properties / value addition

\begin{abstract}
Résumé - Les progrès récents dans l'utilisation de la graine de lin comme source potentielle de valeur ajoutée. La graine de lin (Linum usitatissimum) est une culture oléagineuse qui a pris de l'importance depuis quelques décennies en raison de son profil nutritionnel unique. La graine de lin contient une grande quantité de fibres et constitue une source importante d'acide $\alpha$-linolénique dans l'alimentation des végétariens. Plusieurs études mettent en évidence que les graines de lin apportent des ingrédients fonctionnels et offrent des bénéfices santé. Les acides gras oméga-3, les lignanes et les fibres alimentaires sont des composants bioactifs majeurs des graines de lin qui peuvent être apportés via des produits à valeur ajoutée. La graine de lin a été exploitée avec succès dans la préparation de divers produits à valeur ajoutée. Commercialement, toutes les parties de la graine de lin sont exploitées directement ou après traitement. La consommation de graines de lin dans le régime alimentaire prévient certaines maladies graves comme les maladies coronariennes, le cancer, le diabète, l'obésité, les troubles gastro-intestinaux, rénaux et osseux. À notre connaissance, un nombre limité de revues fait le point sur l'utilisation commerciale de la graine de lin en préparation de divers produits à valeur ajoutée (de boulangerie, laitiers, extrudés, collations, fermentés et autres traditionnels) et sur les effets de l'enrichissement du lin sur le plan nutritionnel, physico-chimique, phytochimique et les propriétés sensorielles de ces produits. À l'avenir, ces données pourraient être utiles pour différentes industries de transformation des aliments.
\end{abstract}

Mots clés : graine de lin / bénéfices santé / alimentation fonctionnelle / propriétés nutraceutiques / valeur ajoutée

\section{Introduction}

Flax seed (Linum usitatissimum) commonly known as linseed is a member of the genus Linum in the family Linaceae.

\footnotetext{
*Corresponding author: yogeshcft10@gmail.com
}

Flax is an oldest agronomic crop having more than 300 species and which are cultivated for food and fiber since ancient times. Flax seed is recognized either by variety or by color (brown and yellow). Brown colored flaxseed is the most common and high in alpha-linolenic acid, while there are two types of yellow colored flaxseed: Omega and Linola (Conforti and Cachaper, 2009). Top most producer of flaxseed in the world is 


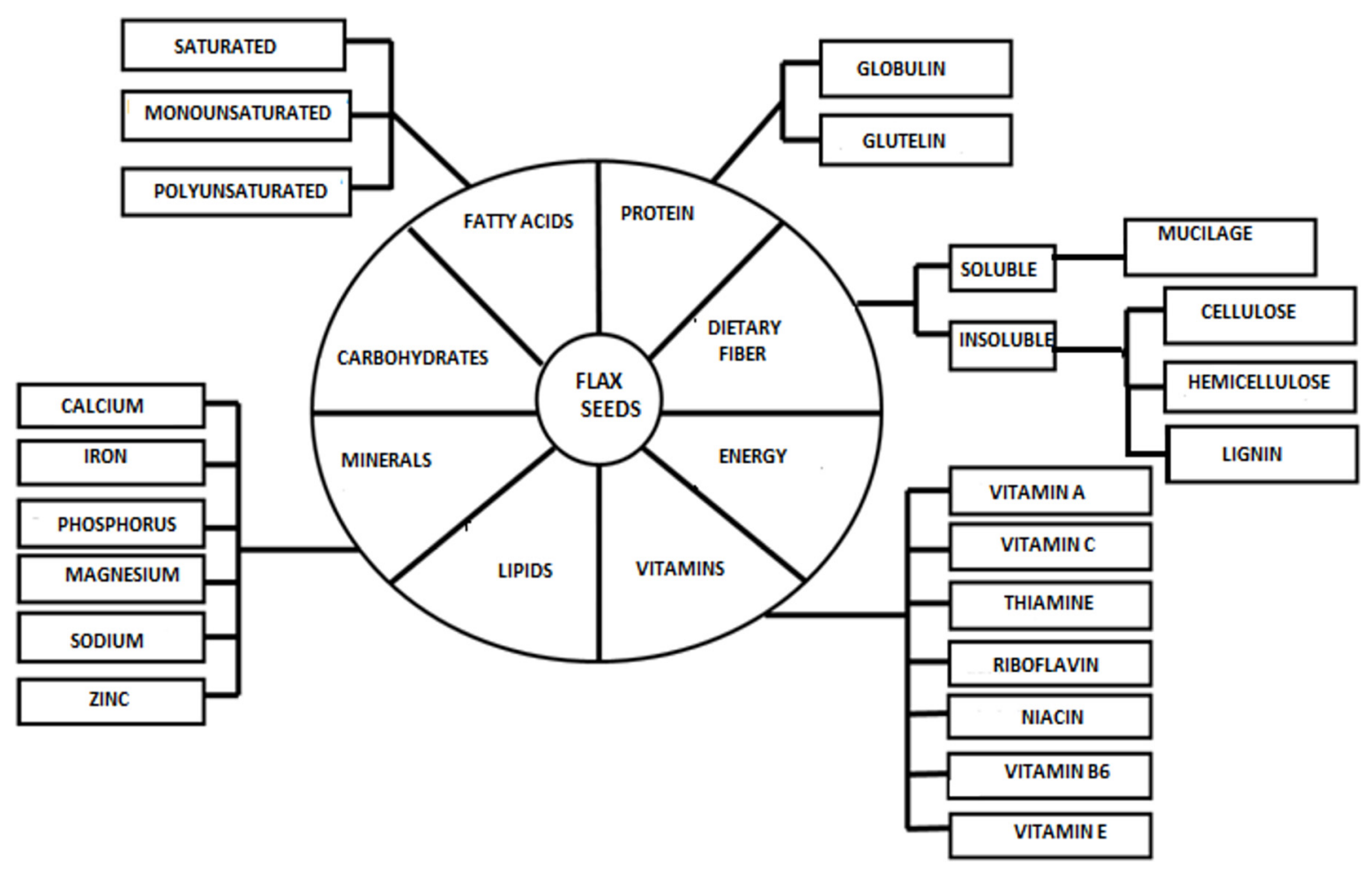

Fig. 1. Nutritional profile of flax seed.

Canada with 0.81 million tons in 2014-2015 (Flax Council of Canada, 2015). Flax seed is cultivated in many parts of world for fiber, oil as well as for medicinal purposes and also as a nutritional product (Kajla et al., 2015). Demand for flaxseed has been increased because of consumer awareness about the relationship between diet and health. Flaxseed is considered as a potential functional food ingredient as it provides various health benefits along with nutritional value (Eyres, 2015).

However, it is an underutilized crop, but gained importance in the last few decades since it has a unique nutrient profile, particularly omega-3 fatty acid, lignans, and fiber (Goyal et al., 2014). Flax seed is an important source of $\alpha$-linolenic acid in the diet of vegetarian people. Therefore, it may serve as an alternate for supplying fatty acid to populations which do not have large access to seafoods (El-Beltagi et al., 2007). The total protein content in flaxseed ranges between 20 to $30 \%$ composed of mainly $80 \%$ globulins and $20 \%$ glutelin (Hall et al., 2006). The amino acid pattern of flax protein is similar to that of soybean protein, which is viewed as one of the most nutritious of the plant proteins (Morris, 2007). Based on a proximate analysis conducted by the Canadian Grain Commission flax is rich in fat, protein and dietary fiber. An analysis of brown Canadian flax averaged $41 \%$ fat, $20 \%$ protein, 28\% total dietary fiber, $7.7 \%$ moisture and 3.4\% ash (Morris, 2007). Cellulose, hemicellulose and lignin are insoluble fiber constituents abundantly found in flaxseed while mucilage gums form the soluble fiber fraction (Morris, 2007). Major lignan present in flaxseed is secoisolariciresinol diglycoside (SDG). Flax seed is an equally good source of minerals, particularly, phosphorus, magnesium, calcium, iron, zinc and very little amount of sodium. Flax seeds also contain anti-nutrients which may pose adverse health effects and may influence the well-being of human population. Major antinutrients in whole flaxseed are cyanogenic glycosides (250 $550 \mathrm{mg} / 100 \mathrm{~g}$ ) (Singh et al., 2011), while the phytic acid content of flaxseed meal is $2.3-3.3 \%$ which result in decreased absorption of nutrients. Hydrogen cyanide released from flaxseed is minimal and lower than the toxic or lethal dose. The release of hydrogen cyanide is approximately 5-10 mg from 12 tablespoons (recommended daily intake of flaxseed). This value is much lower than the acute toxic dose which is estimated to be $50-60 \mathrm{mg}$. Also, human beings can detoxify cyanide levels below 30-100 mg/day (Roseling, 1994). Roasting is generally done to remove cyanogenetic glycosides. Wanasundara et al. (1993) described a method for elimination of cyanogenetic glycosides from flaxseed meal in which solvent extraction consisting two phases i.e., hexanes and alkanol was used either with the addition or without water or ammonia. The alkanol could be methanol, ethanol or isopropanol. By utilizing methanol solutions, more than $90 \%$ of the cyanogenetic glycosides viz. linustatin and neolinustatin were removed. Proximate composition and antinutrient content vary with varietal differences (Kajla and Sharma, 2016). Nutritional profiles of flaxseed are reported in Figure 1. It is evident from the data reported in Table 1 that flaxseed contains the second highest amount of protein $(18.29 \%)$ followed by sesame seeds $(17.73 \%)$, chia seed $(16.54 \%)$ and safflower seeds (16.18\%). Fiber content in flaxseeds $(27.3 \%)$ is more than sesame seeds $(11.8 \%)$ and sunflower seed kernels $(8.6 \%)$. Also, polyunsaturated fatty acid is present in highest amounts $(28.73 \%)$ in flaxseed when compared with other oilseeds as presented in Table 1. Along with that flaxseed is also a good source of B-vitamins (USDA, 2016). 
P. Kaur et al.: OCL 2018, 25(3), A304

Table 1. Nutritional profile of various oilseeds (values per $100 \mathrm{~g}$ dry basis) (USDA May, 2016 report).

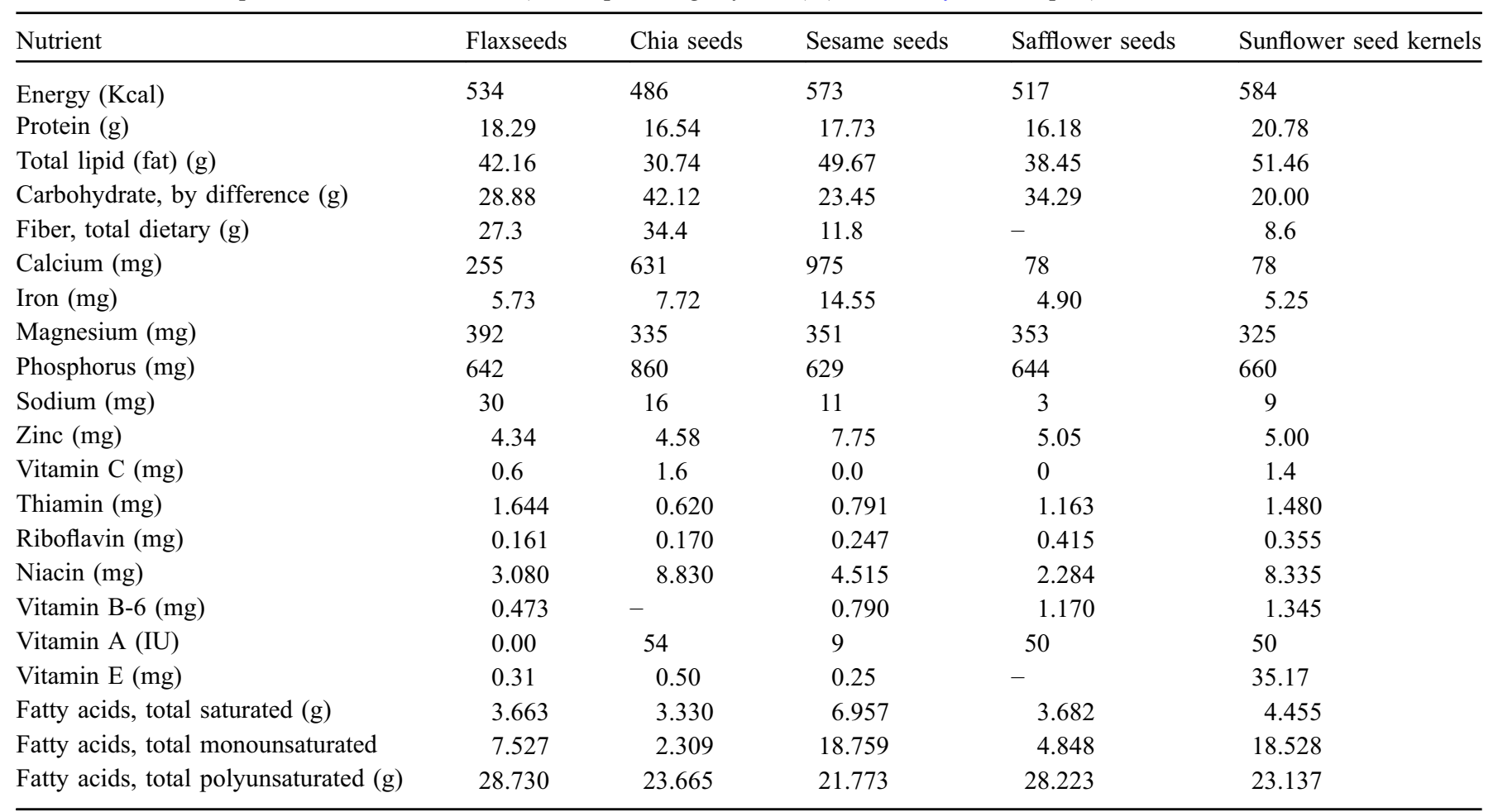

\subsection{Health benefits of flaxseed}

Functional ingredients present in flaxseed make it beneficial for critical diseases like cardiovascular diseases, cancer, diabetes, obesity, renal and bone disorders (Katare et al., 2012). Dietary flaxseed modifies cardiovascular risk factor by improving lipid profile in hyperlipidemic patients. In vivo studies conducted on rats indicated that flaxseed has the ability to protect from breast, colon and ovarian cancer by preventing the formation of tumor and additionally diminishing blood vessel cell development (Truan et al., 2012). High content of SDG lignin in flaxseed is possibly responsible for a breast tumor-reducing effect (Chen et al., 2011). Flaxseed has a protective effect against diabetes risk due to presence of dietary fiber, lignan, and $\omega-3$ fatty acid (Adlercreutz, 2007).

Kapoor et al. (2011) observed that postprandial blood glucose was decreased by 7.9 and $19.1 \%$, respectively, by supplementation of flaxseed powder (15 and $20 \mathrm{~g} /$ day) for 2 months in diabetic females. Non-starch dietary fibers of flaxseed delay stomach emptying and decrease absorption of nutrients in the small intestine. Thus, it can prevent obesityrelated diseases (Singh et al., 2011). Effects of flax fiber on gastrointestinal motility, constipation, glucose tolerance, hypocholesterolemic effect and fermentation have been described comprehensively in various reviews and articles (Mani et al., 2011; Kristensen et al., 2012, 2013).

Omega-3 fatty acids possess anti-inflammatory properties so they protect the destruction of kidneys in adults. More consumption of omega-3 polyunsaturated fatty acid reduced occurrence of chronic kidney diseases (Gopinath et al., 2011).
Dietary flaxseeds have ability to increase blood levels of ALA, even when incorporated into baked goods like breads or muffins in ground or milled form.

\section{Value added products prepared by incorporation of flax seed}

Value added products are prepared for enhancing the value of food items through the addition of ingredient, processing or packaging. Value added food products are more attractive and usable by the consumer than original commodity. Some examples of value added products are breakfast cereals, skim milk, ice cream, yogurt, cheeses, extruded snacks, etc.

Thompson and Cunnane (2003) provided the current status of the knowledge about the analysis and composition of flaxseed, the metabolism and bioavailability of its major components, the effect of flaxseed on development and disease, processing of flaxseed, and availability of flaxseed products which created interest amongst consumer and food industry about flax seed as a beneficial component in the human diet. Commercially, all parts of flaxseed plant are exploited directly or after processing in preparation of various value added products. When flax is consumed by humans, then it is usually described as flaxseed whereas when it is used for industrial purposes, then it is described as linseed (Morris, 2007). As a functional food ingredient, flaxseed (milled or ground) and flaxseed oil has been incorporated into baked (Tab. 2), dairy (Tab. 3), extruded (Tab. 4), snacks and other products (Tab. 5). Commercial use of flax in various food products is presented in this review. 
Table 2. Baked products prepared by flaxseed fortification in different forms and at different concentrations.

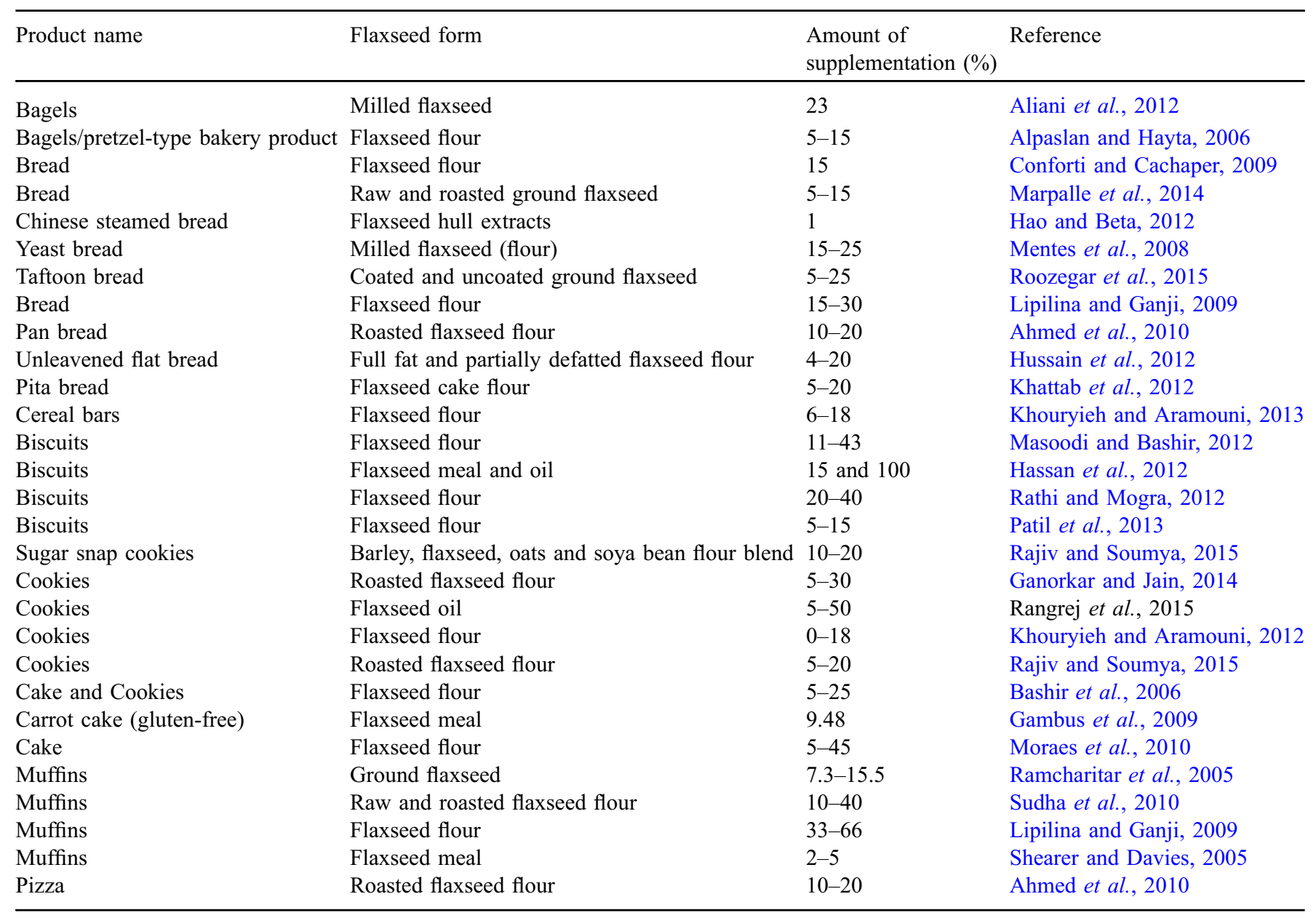

Table 3. Dairy products prepared by flaxseed fortification in different forms and at different concentrations.

\begin{tabular}{lllll}
\hline Product name & Flaxseed form & Processing method & $\begin{array}{l}\text { Amount of } \\
\text { supplementation }\end{array}$ & Reference \\
\hline Dahi (Indian Yogurt) & $\begin{array}{l}\text { Microencapsulated flaxseed } \\
\text { oil powder (MEFOP) }\end{array}$ & Fermentation & $1-3 \%$ & Goyal et al., 2016 \\
Ice cream & Flaxseed oil & Freezing & $0-12 \%$ & Goh et al., 2006 \\
Cheese & Flaxseed lignan (SDG) & Pasteurization and fermentation & $1 \mathrm{~g} / 10 \mathrm{~L}$ & Hyvarinen et al., 2006 \\
Yogurt & Flaxseed lignan (SDG) & Fermentation & $100 \mathrm{mg}$ & Hyvarinen et al., 2006 \\
Milk & Flaxseed lignan (SDG) & Heat treatment & $1 \%$ Hyvarinen et al., 2006 \\
Whey drinks & Flaxseed lignan (SDG) & Pasteurization & $10 \mathrm{ml}$ ml & Hyvarinen et al., 2006 \\
Butter & Flaxseed additive & - & $0.8-1.6 \%$ & Ivanov et al., 2011 \\
\hline
\end{tabular}

\subsection{Bakery products}

The baking industry is one of the leading systematized processed food industry. Bakery products are popular due to their convenience, low price and ready-to-eat nature, easy transportation, availability in numerous tastes and textural profiles. The foremost benefit of bakery products is docility for fortification with cereals, millets or other ingredients (Gat and Ananthanarayan, 2015a, b). Therefore, these products are an effective medium for delivering functional ingredients to consumers. Commercially available cookies are mostly deficient in ALA and dietary fiber (Ganorkar and Jain, 2014). Refined ingredient usage makes biscuits deprive of grain components that are protective of health (Fardet, 2010).

Flax seed can be incorporated into baked good as whole, milled, ground, roasted and in the form of oil. Flaxseed addition in bakery products has been a challenge for various researches due to oxidative instability of flaxseed at high 
Table 4. Extruded products prepared by flaxseed fortification in different forms and at different concentrations.

\begin{tabular}{llll}
\hline Product name & Flaxseed form & Amount of supplementation & Reference \\
\hline Extruded noodle & Flaxseed flour & $10 \%$ & Bhise et al., 2014 \\
Macaroni & Ground whole flaxseed and ground flaxseed hull & $15 \%$ & Lee et al., 2004 \\
Pasta & Flaxseed flour & $15 \%$ & Manthey et al., 2008 \\
Pasta & Flaxseed flour & $5-20 \%$ & Sinha and Manthey, 2008 \\
Pasta & Defatted Milled Flaxseed & 10 and 30 g & \\
Puffs & Flaxseed with corn meal & $15 \%$ & Wu et al., 2007 \\
Corn and flaxseed snacks & Flaxseed flour & $16 \%$ & Trevisan and Arêas, 2012 \\
Extruded snacks & Flaxseed flour & $0-20 \%$ & Mesquita et al., 2013 \\
Bean snack & Milled flaxseed & $5-20 \%$ & Vadukapuram et al., 2014 \\
Spaghetti & Ground flaxseed & $5-15 \%$ & Manthey et al., 2002 \\
Cereal Based products & Flaxseed meal & $9 \%$ & Giacomino et al., 2013 \\
\hline
\end{tabular}

Table 5. Other traditional products prepared by flaxseed fortification in different forms and at different concentrations.

\begin{tabular}{|c|c|c|c|c|}
\hline Product name & Flaxseed form & Processing method & $\begin{array}{l}\text { Amount of } \\
\text { supplementation } \\
(\%)\end{array}$ & Reference \\
\hline Vegetable chilla & Flaxseed flour & Shallow frying & $20-40$ & Rathi and Mogra, 2012 \\
\hline Wheat chips & Flaxseed flour & Frying & $10-20$ & Yuksel et al., 2014 \\
\hline Energy bar & Flaxseed flour & Freezing & $0-20$ & Mridula et al., 2013 \\
\hline Vermicelli & Flaxseeds & - & 10 & Jain et al., 2014 \\
\hline Dry-fermented sausages & Flaxseed oil & Fermentation & 3.3 & Ansorena and Astiasarán, 2004 \\
\hline Tahina & Roasted flaxseed flour & Grinding and mixing & $25-100$ & Ahmed et al., 2010 \\
\hline Manchurian & Flaxseed flour & Shallow frying & $20-40$ & Rathi and Mogra, 2012 \\
\hline
\end{tabular}

temperatures and during storage. Recent studies have suggested that flaxseed has been used in various bakery products like bagels, breads, biscuits, cookies, muffins, pizza, buns and patties at different levels (Kaur et al., 2017) (Tab. 2).

Addition of flax seeds into various bakeries and other cereal products gave positive results for enhancing overall nutritional quality. Incorporation of $10 \mathrm{~g}$ flaxseed per $100 \mathrm{~g}$ refined flour into functional bread resulted in an increase in water absorption, dough stickiness and crumb softness (Marpalle et al., 2014). Tafton bread with 5 and 15\% coated ground flaxseed with arabic gum or hydrogenated fat had acceptable rheological and organoleptic characteristics (Roozegar et al., 2015). Flaxseed muffins (7.3\%, 11.6\% and $15.5 \%$ ) were less acceptable than control muffins on the basis of sensory parameters, but they provide $16 \%$ of the dietary fiber requirement (Ramcharitar et al., 2005). Flaxseed cookies ( 6 and 12\%) were accepted by the consumer without adversely affecting physical and sensory quality (Khouryieh and Aramouni, 2012). Shortening can be replaced with flaxseed oil up to $30 \%$ in cookies and it enhances $\omega-3$ fatty acid by $14.14 \%$ in flaxseed oil cookies (Rangrej et al., 2014). Chemical evaluation of some products (pan bread-pizzaTahina) showed that protein content, fat, fiber, and ash content increased with addition of flaxseed to wheat flour by $15 \%$ while carbohydrate decreased in bread and pizza (Ahmed et al., 2010).

\subsection{Dairy products}

Dairy-based products are a major part of functional foods. Functionality of dairy products can be developed and designed simply by modifying and/or enriching healthy nature of the original base. Type of milk and culture, the amount of milk fat and nonfat milk solids, fermentation and temperature used affect aroma, body and flavor of cultured dairy products. Milk and milk products have been proven to be a successful medium for delivering bioactive ingredients (Rowan et al., 2005). Value-added dairy products include low-lactose or lactose-free products, hypoallergenic formulations with hydrolyzed protein for milk-hypersensitive infants, milk enriched with calcium, vitamins, etc. (Ozer and Kirmaci, 2010). Flaxseed oil and flaxseed lignan have also been supplemented into milk and various dairy products such as ice cream, cheese, yogurt, whey drinks and butter (Tab. 3). 2\% (w/w) flaxseed oil in a $12 \%(\mathrm{w} /$ w) ice cream mix can be incorporated without significantly affecting the overall functionality of ice cream. SDG added to milk, yogurt, and cheese were found to withstand hightemperature pasteurization, fermentation, and milk renneting processes well (Hyvarinen et al., 2006). Microencapsulated flaxseed oil powder was fortified in dahi (Indian yoghurt) at three different formulations as 1,2 and $3 \%$, which could serve as a potential delivery system of omega- 3 fatty acids (Goyal et al., 2016). 


\subsection{Extruded products}

Extrusion cooking technology plays a key role in many foodprocessing industries as a continuous cooking, mixing, shearing and forming process (Ananthanarayan et al., 2017). It can be used to produce a number of foods and feed applications such as snacks, ready to eat (RTE) cereals, confectionery products and crisp breads. Convenience, value, attractive appearance and particular texture of extruded foods are the main reason of consumer acceptance of these foods (Anton et al., 2009).

Some extruded products prepared by flaxseed fortification are presented in Table 4. An extruded flaxseed-containing product that can be consumed as a breakfast cereal or snack may encourage consumption of flaxseed and provide health benefits for consumers (Wu et al., 2007). Manthey et al. (2008), Sinha and Manthey (2008), Gupta (2012) have developed flaxseed-based pasta which ensures functional properties of flaxseed. Under conditions of $10 \%$ flaxseed flour, $230 \mathrm{rpm}$ screw speed, temperature of $90^{\circ} \mathrm{C}$ and moisture of $12 \%$ an expanded snack product with good physical properties can be obtained (Mesquita et al., 2013). Vadukapuram et al. (2014) reported that in extruded bean snack, omega-3 fatty acids and bulk density, improved with increasing concentration of flaxseed $(5-20 \%)$. Similar results were represented by Giacomino et al. (2013) in cereal bars, enriched with an extruded flax seed meal which provide an adequate nutritional quality of proteins, dietary fiber and $\omega 6: \omega 3$ ratio. With incorporation of $10 \%$ flaxseed flour for the preparation of extruded noodles indicated improvement in protein content, but as the level of flaxseed flour increased it shows the negative effect on sensory, color and cooking characteristics of noodles (Bhise et al., 2014).

\subsection{Snack products}

A snack is part of the food typically eaten in between meals, but not as a substitute for a meal. Snacks provide considerably less calories than would be consumed in a typical meal. Conventionally, snacks are prepared from ingredients such as cold cuts, fruit, leftovers, nuts and sandwiches, etc. Processed snack foods are convenience food and less perishable than prepared foods. They often contain sweeteners, preservatives, and appealing ingredients such as chocolate, peanuts, and specially-designed flavors (for example flavored potato chips). In recent years, interest of the snack food industry towards developing new products to attract consumers has increased (Meethal et al., 2017). Addition of flaxseed (10\%) resulted in an increase of omega-3 fatty acids and protein of wheat chips samples and overall acceptability of chips increased with increase of frying temperature (Yuksel et al., 2014).

Addition of reddish brown flax seeds into snacks enhances texture and gives a superior taste along with a pleasant nutty flavor (Manthey et al., 2002). Moreover, flax seeds have a healthy lipid profile which alters the lipid content of snack products and modify omega-3 polyunsaturated fatty acid profile. Thus, it improves the nutritional quality of these snacks and reduces risk of chronic maladies in the community (Ansorena and Astiasarán, 2004). A snack made with flaxseed and corn showed a sevenfold increase in dietary fiber, $100 \%$ increase in protein content and was as acceptable as commercial corn snacks (Trevisan and Arêas, 2011).

\subsection{Fermented products}

Fermentation, also called souring, is a traditional preservation method, which can be used to improve the shelf life and digestibility of the products (Chavan et al., 2018). Fermented cereal products containing live lactic acid bacteria are known and fermentation of flaxseed-based material is suggested due to its advantageous effects. Crushed or crushed and milled flaxseed is supplemented with other cereals or plant seeds, e.g. oat, buckwheat or soy to prepare flaxseed-based fermented products.

Among existing beverage matrices, fruits/vegetable juice matrix is noted to be a popular format in the fast moving consumer goods section. Solubility, hydration rate, and thickening properties of ground flaxseed are important considerations when adding flaxseed to beverages. Flaxseed-based fermented beverages can be prepared with the help of lactic acid fermentation of flaxseed suspension, which is further seasoned with the help of different fruit/vegetable juice blends. Further, aroma and flavor of such fermented beverages is improved with the help of different natural and artificial flavor extracts. Texture and rheological structure of flaxseedbased fermented products can be improved with the addition of different additives. Cloud stability and the juice turbidity of carrot juice were lowered, with the addition of flaxseed gum as a hydrocolloid at different concentrations, which abolish creamy appearance (Shakeel et al., 2015). The formation of stable emulsion is the major problem while preparing flaxseed oil enriched beverages. One of the recent research study report on the formation of stable emulsions of flaxseed oil $(1 \% \mathrm{v} / \mathrm{v})$ in carrot juice using $20 \mathrm{kHz}$ ultrasound at $176 \mathrm{~W}$ and $4 \mathrm{~min}$ of processing time (Shanmugam and Ashokkumar, 2014).

\subsection{Other traditional products}

Rathi and Mogra (2012) tried traditional snacks, chapatti, khakhra, vegetable chilla and manchurian by supplementation of flaxseed flour at different levels (Tab. 5). Appetizer, starter and precooked food recipes viz. vegetable soup, vermicelli and bhelpuri chat prepared with the incorporation of flax seeds had good nutritional and functional properties. Also, these low fat recipes are good to maintain a healthy heart (Jain et al., 2014). Flax chutney powder, a palatable functional food adjunct, was prepared by mixing roasted and powdered flax seeds with other selected spice ingredients which is having high nutraceutical properties (Rao et al., 2011). Also, flaxseed flour can be used as a functional ingredient to enrich traditional animal origin products such as beef patties which has increased the energy value as well as polyunsaturated/saturated fatty acid ratio (Bilek and Turhan, 2009).

\section{Effects of flaxseed fortification on different properties of value added products}

\subsection{Nutritional properties}

Balanced diet is vital for good health and well-being. The food delivers energy, protein, fat, vitamins and minerals for living, growth and to work properly. Wide variety of different foods is required to provide precise amounts of nutrients for good health. Unhealthy eating habits are the leading cause of 
death and increased risk of numerous diseases. Diet and nutrition play an important role in critical ailments such as coronary heart diseases, obesity, cancer, type- 2 diabetes, bone disorders, dental caries, gall bladder disease, dementia and nutritional anemia.

Flaxseed flour greatly enhanced nutritional qualities without affecting the overall acceptability of products. Ash, protein, fat and crude fiber contents of flaxseed cookies and biscuits were more than control which could be accounted by the fact that flaxseed is far higher in mineral, fat, protein and fiber content than wheat flour (Patil et al., 2013; Masoodi and Bashir, 2012). Sudha et al. (2010) and Bashir et al. (2006) reported similar results for flaxseed incorporated muffins; cookies and cakes respectively. Fortification of biscuits with flaxseed flour resulted in decreased carbohydrate content as compared to control (Masoodi and Bashir, 2012). Results indicated that flaxseed flour incorporation considerably enhanced nutritional quality, particularly protein, fat, crude fiber, iron, calories and omega-3 content of cereal and energy bars (up to $12 \%$ and 5-20\%, respectively) without affecting their sensory and quality properties (Khouryieh and Aramouni, 2013; Mridula et al., 2013).

The major benefit of flax seed enrichment is generally an increase in omega-3 fatty acid content of products. Flax seed oil enriched biscuits were particularly rich in alpha linolenic acid $(42.76 \%)$ and they contained a less amount of linoleic acid (13.52\%) (Hassan et al., 2012). Rangrej et al. (2014) have also represented similar results that omega-3 fatty acid increased from 0 (control) to $14.14 \%$ with incorporation $30 \%$ flaxseed oil in cookies. Cakes and breads prepared with $30 \%$ flaxseed flour received claims of good and excellent source of dietary fiber and linolenic acid (Moraes et al., 2010; Lipilina and Ganji, 2009).

As a baking ingredient, ground flaxseed does not lose significant amounts of ALA during baking (Ganorkar and Jain, 2014). Also, extruding, drying and cooking had little or no effect on stability of lipids in macaroni containing flaxseed (Lee et al., 2004). This might be due to the high natural level of antioxidant active lignans, which contribute to the oxidative stability of flaxseed oil and products with incorporated flax seed. Levels of soluble, insoluble and total dietary fiber and essential amino acids were higher in unleavened flat bread with added flaxseed when compared with control (Hussain et al., 2012). Trevisan and Arêas (2011) also represented similar results for corn-flaxseed snack which had a sevenfold increase in dietary fiber, almost $100 \%$ increase in protein content compared to pure corn snack.

\subsection{Phytochemical properties}

Many researchers have identified flaxseed as a new source of nutraceutical with desirable functional characteristics because of its high content of phytochemicals (Conforti and Cachaper, 2009). Consumers also now believe in health benefits or nutrition as one of the desirable food qualities. Among other materials, incorporation of flaxseed has been shown to cause a positive impact on levels of proteins and dietary fiber of cereal-based traditional products. Incorporation of flaxseed believed to promote utilization as well as increase the nutraceutical appeal of the processed food product.
Antioxidant activity and total phenolic content of Chinese steamed bread containing barley, flaxseed, and barley-flaxseed hull extracts were increased compared to their control sample (Hao and Beta, 2012). Rao et al. (2011) prepared an Indian traditional product (chutney powder) containing 50\% flaxseed powder and reported that the total phenol content of functional food adjunct increased with addition of flaxseed powder. Also, another researcher (Kaur and Das, 2014) reported similar observations of increases in phytochemical properties (total phenol content and antioxidant) with the incorporation of flaxseed in functional dry soup mix.

\subsection{Physico-chemical properties}

Physical properties are used to observe and describe matter without changing the composition of matter. In bakery product weight, diameter, thickness and spread ratio are important physical properties. While in case of extruded product expansion ratio, bulk density, water absorption and water solubility are important physical properties. Increasing levels of flaxseed flour resulted in greater thickness and increase in diameter than that of control biscuits and cookies, but spread ratio was significantly decreased (Ganorkar and Jain, 2014; Patil et al., 2013; Hussain et al., 2012). Whereas, Rangrej et al. (2014) observed that the increase in the flaxseed oil level increased spread ratio and breaking strength of cookies. Overall loaf volume of cakes decreased as the amount of flaxseed was increased in the treatment (Bashir et al., 2006). Possible reason could be that gluten development was inhibited with increasing flaxseed level, therefore decrease in height was observed. Also, the high fat content of flaxseed flour causes less air entrapment (Khouryieh and Aramouni, 2012).

Mesquita et al. (2013) concluded that under the conditions of $10 \%$ flaxseed flour, $230 \mathrm{rpm}$ screw speed, temperature of $90{ }^{\circ} \mathrm{C}$ and moisture of $12 \%$, extruded snack products with good physical properties could be obtained. Ahmed (1999) reported that addition of flaxseed flour (5-20\%) decreased expansion ratio and increased bulk density resulting a denser extruded corn-based flax snack product. In addition, extrudate became darker, and both water absorption and water solubility decreased with increasing flaxseed flour content.

Baked as well as extruded products have different risks in terms of the formation of thermal process contaminants. Particularly in breads, the temperature of the crust is approaching to oven temperature as soon as the moisture content decreases to a critical level. This makes the crust susceptible to form acrylamide during baking. Gokmen et al. (2011) reported that with the use of nanoencapsulated flax seed oil, it is possible to reduce the risk associated for acrylamide formation in bread. In addition, Anese et al. (2015) suggested that acrylamide formation was greater for the omega-3 enriched biscuits baked at ambient pressure than for samples cooked at reduced pressure. While Bartkiene et al. (2016) showed lactic acid fermentation as another way to reduce the amount of acrylamide in wheat biscuits supplemented with flaxseed and lupine.

\subsection{Color properties}

Color of food product is a key factor which influences customer selection. The first decision about a food's quality is 
most often taken by its appearance which includes color, shape, texture and other surface characteristics (Gat and Ananthanarayan, 2016). Color plays an important role in food choice in influencing taste thresholds, sweetness, perception, food preference, pleasantness and acceptability.

Flaxseeds have a significant effect on color scores i.e., $\mathrm{L}^{*}$ (lightness/darkness), a*(redness/greenness) and $b^{*}$ (yellowness/blueness) of various fortified food products. Color values of different flaxseed supplemented products like cookies (Ganorkar and Jain, 2014), muffins (Shearer and Davies, 2005), bars (Khouryieh and Aramouni, 2013), pasta (Sinha and Manthey, 2008) and extrudates (Vadukapuram et al., 2014) were decreased. Flaxseed addition, significantly $(p<0.05)$ decreased lightness and increased redness of bars (Khouryieh and Aramouni, 2013). Increased flaxseed flour level in cookies led to considerably darker and browner appearance of cookies possibly due to Maillard browning reactions during cooking of flaxseed flour (Khouryieh and Aramouni, 2012).

\subsection{Textural and rheological properties}

Texture of foods comprises a complex group of physical properties that result from structural makeup of food. Texture plays a key role in consumer acceptance and market value of food products. Texture characteristics are important factors for the raw products and for processing, preparation, and consumption. Adhesiveness, chewiness, cohesiveness, consistency, crispiness, crunchiness, elasticity, extensibility, firmness, fracturability, gumminess, hardness, rupture strength, springiness, stiffness, stringiness and other parameters are important textural parameters.

Texture analysis of cookie doughs showed that there was a decrease in hardness and springiness values, whereas gumminess values increased by $10-20 \%$ multigrain powder containing flaxseed flour (Rajiv and Soumya, 2014). Rheological characteristics of different dough were investigated using farinograph and extensograph. Dough properties such as peak viscosity, dough stability, resistance to the extension and extensibility values were decreased with increase in substitution level (5-20\%) of roasted ground flaxseed (Rajiv et al., 2011).

Khattab et al. (2012) observed that defatted flaxseed flour incorporation (up to 15\%) into pita bread had decreased moisture loss and increased alkaline water retention capacity and thus improved its textural characteristics without affecting physical and sensory properties. Whereas, after incorporation of $15 \%$ roasted flaxseed flour into control cookies an increasing hardness was observed by Ganorkar and Jain (2014).

The flax seed bread had a softer texture and lower staling rate comparisons to control bread (Roozegar et al., 2015). Crumb softness of bread increased with increase in flaxseed flour level (Marpalle et al., 2014). Goh et al. (2006) indicated that addition of flaxseed oil into ice cream resulted in a poor texture probably due to very low melting temperature $\left(<12^{\circ} \mathrm{C}\right)$ of flaxseed oil. Hardness values of wheat chips samples were decreased with increase of frying temperature because the addition of flaxseed flour increased dry matter and protein content of samples (Yuksel et al., 2014).

\subsection{Sensory properties}

Sensory evaluation measure, analyze and interpret responses to products as perceived by the senses of sight, smell, touch, taste, and hearing. It is a scientific method which explores specific characteristics of an ingredient or food product by comparing similarities and differences in a range of products. Appearance, color, flavor, texture, odor, touch and temperature, etc. are sensory properties by which human responses to composition of food and drink are analyzed. At present, new challenges faced by the food industry are gradually transforming sensory to a more proactive role for producing new products based on unique sensory properties.

Studies have shown that increase in substitution level of flaxseed in different products has decreased sensory scores for different parameters as compared to standard products, but at a certain level it was acceptable (Ramcharitar et al., 2005; Rangrej et al., 2014; Masoodi and Bashir, 2012; Bashir et al., 2006; Gambus et al., 2009). Aliani et al. (2012) showed that bagels prepared by flaxseed incorporation were acceptable in terms of appearance, color, texture and flavor. Results of Patil et al. (2013) also indicated that biscuit containing $10 \%$ flaxseed had higher acceptability and there was no mark reduction in score for color, taste and appearance of biscuit.

Khouryieh and Aramouni (2013) observed that overall acceptability for both $12 \%$ flax bars and control was same at 9point hedonic scale. Whereas Mridula et al. (2011) indicated that omega-3 fatty acid rich energy bar of acceptable quality could be prepared using $15 \%$ flaxseed and $45 \%$ sweeteners with other ingredients at commercial scale and also stored well for 90 days at refrigerated condition. Higher than $30 \%$ incorporation of flaxseed flour adversely affected the appearance of snack products, i.e. color and taste wise bitterness was detected by panel members (Rathi and Mogra, 2012). Flavor is the main criterion that makes the product to be liked or disliked. Flaxseed has a unique pleasant nutty flavor that compliments many combinations. Butter with flax seed additive had pure creamy flavor and odor without flavor and odor of additive, yellow color and good spread ratio as well as plasticity (Ivanov et al., 2011).

\section{Effect of flaxseed fortification on shelf-life of value added products}

Ground or whole flax seed can be added to almost any baked product to add a nutty flavor to bread, waffles pancakes and other products. But the major cause of concern during storage is lipid oxidation, which is a major cause of loss of nutritional and sensory quality of processed foods. Lipid oxidation can be limited during processing, but it might increase during storage. Packaging under nitrogen or vacuum in opaque containers may further protect processed food during storage. In addition, external factors during storage such as temperature, light and oxygen exposure need to be considered while storing processed food products. In flaxseed incorporated food applications, however, quality factors such as the sensory attributes and the shelf stability of the targeted food product are important, since the highly unsaturated nature of the predominant fatty acid may lead to early rancidity and result in undesirable sensory taints. 
Some of the researchers have demonstrated storage stability effect of flaxseed incorporated products such as the texture of the flaxseed cookies slight decreased (Rajiv et al., 2011); the color of the flaxseed chutney powder retained well, and scores for the characteristic flavor decreased significantly (Rao et al., 2011); flaxseed oil cookies showed higher increases in peroxide value as compared with the control cookies (Rangrej et al., 2014); overall acceptability score for flavor and taste were at par for omega-3 rich energy bar samples having 10\% flaxseed (Mridula et al., 2011).

\section{Conclusion}

The purpose of this review was to summarize the incorporation of flaxseed to enrich different products such as baked, dairy, extruded and snacks. Along with that present review focuses on the impact of different amount of supplementation on nutritional, physicochemical and sensory properties of these products. Studies revealed that significant increase in nutritional value of value added products was observed in terms of ash, protein, dietary fiber and omega-3 fatty acid when enriched with flaxseed. With the incorporation of flaxseed in suitable concentration helped to improve physicochemical, textural, color, and sensory properties of different products. More research is needed to develop quick, reproducible and cost-effective practices for developing value added flax seed enriched products.

\section{References}

Adlercreutz H. 2007. Lignans and human health. Crit Rev Clin Lab Sci 44: 483-525. Doi: 10.1080/10408360701612942.

Ahmed ZS. 1999. Physico-chemical, structural and sensory quality of corn-based flax-snack. Food/Nahrung 43: 253-258. Doi: $10.1002 /$ (sici)1521-3803(19990801)43:4<253::aidfood253>3.3.co;2-v.

Ahmed MG, EA Header, Fatma A El-Sherif, MS El-Dashlouty, SA El-Brollose. 2010. Sensory, chemical and biological evaluation of some products fortified by whole flaxseed. Egypt J Agric Res 88: 257-271.

Aliani M, Ryland D, Pierce GN. 2012. Effect of flax addition on the flavor profile and acceptability of bagels. J Food Sci. Doi: 10.1111/j.1750-3841.2011.02509.x.

Alpaslan M, Hayta M. 2006. The effects of flaxseed, soy and corn flours on the textural and sensory properties of a bakery product. J Food Qual 29: 617-627.

Ananthanarayan L, Gat Y, Kumar V, Panghal A, Kaur N. 2017. Extruded black gram flour: Partial substitute for improving quality characteristics of Indian traditional snack. J Ethnic Foods. Available from doi.org/10.1016/j.jef.2017.10.001.

Anese M, Valoppi F, Calligaris S, et al. 2015. Omega-3 enriched biscuits with low levels of heat-induced toxicants: Effect of formulation and baking conditions. Food Bioprocess Technol 9: 232-242. Doi: 10.1007/s11947-015-1613-x.

Ansorena D, Astiasarán I. 2004. The use of linseed oil improves nutritional quality of the lipid fraction of dry-fermented sausages. Food Chem 87: 69-74. Doi: 10.1016/j.foodchem.2003.10.019.

Anton AA, Fulcher RG, Arntfield SD. 2009. Physical and nutritional impact of fortification of corn starch-based extruded snacks with common bean (Phaseolus vulgaris L.) flour: Effects of bean addition and extrusion cooking. Food Chem 113: 989-996. Doi: 10.1016/j.foodchem.2008.08.050.
Bartkiene E, Jakobsone I, Pugajeva I, et al. 2016. Reducing of acrylamide formation in wheat biscuits supplemented with flaxseed and lupine. LWT-Food Sci Technol 65: 275-282. Doi: 10.1016/j.lwt.2015.08.002.

Bashir S, Masud T, Latif A. 2006. Effect of flaxseed (Linum usitatissimum) on the baking properties of cakes and cookies. Int $J$ Agric Res 1: 496-502. Doi: 10.3923/ijar.2006.496.502.

Bhise S, Kaur A, Aggarwal P. 2014. Development of protein enriched noodles using texturized defatted meal from sunflower, flaxseed and soybean. J Food Sci Technol 52: 5882-5889. Doi: 10.1007/ s13197-014-1630-1.

Bilek AE, Turhan S. 2009. Enhancement of the nutritional status of beef patties by adding flaxseed flour. Meat Sci 82: 472-477. Doi: 10.1016/j.meatsci.2009.03.002.

Chavan M, Gat Y, Harmalkar M, Waghmare R. 2018. Development of non-dairy fermented probiotic drink based on germinated and ungerminated cereals and legume. LWT-Food Sci and Technol 91: 339-344. Available from doi.org/10.1016/j.lwt.2018.01.070.

Chen J, Saggar JK, Ward WE, Thompson LU. 2011. Effects of flaxseed lignan and oil on bone health of breast-tumor-bearing mice treated with or without tamoxifen. $J$ Toxicol Environ Health 74: 757-768.

Conforti FD, Cachaper KF. 2009. Effects of selected antioxidants on physical and sensory characteristics of yeast bread containing flaxseed meal. Int J Cons Stud 33: 89-93. Doi: 10.1111/ j.1470-6431.2008.00729.x.

El-Beltagi, HS, Salama ZA, El-Hariri DM. 2007. Evaluation of fatty acids profile and the content of some secondary metabolites in seeds of different flax cultivars (Linum usitatissimum L.). Gen Appli Plant Physiol 33: 187-202.

Eyres, L. 2015. Flaxseed fibre-a functional superfood? Food $N Z$ 15(5): 24.

Fardet A. 2010. New hypotheses for the health-protective mechanisms of whole-grain cereals: what is beyond fibre. Nutr Res Rev 23: $65-134$.

Flax Council of Canada. 2015. http://flaxcouncil.ca/resources/statis tics/. Accessed 25 December 2015.

Gambus H, Gambus F, Pastuszka D, et al. 2009. Quality of gluten-free supplemented cakes and biscuits. Int J Food Sci Nutr 60: 31-50. Doi: $10.1080 / 09637480802375523$.

Ganorkar PM, Jain RK. 2014. Effect of flaxseed incorporation on physical, sensorial, textural and chemical attributes of cookies. Int Food Res J 21: 1515-1521.

Gat Y, Ananthanarayan L. 2015a. Effect of extrusion process parameters and pregelatinized rice flour on physicochemical properties of ready-to-eat expanded snacks. J Food S Technol 52: 2634-2645. Doi: 10.1007/s13197-014-1378-7.

Gat Y, Ananthanarayan L. 2015b. Physicochemical, phytochemical and nutritional impact of fortified cereal-based extrudate snacks. NUTRAfoods 14: 141-149.

Gat Y, Ananthanarayan L. 2016. Use of paprika oily extract as preextrusion colouring of rice extrudates: impact of processing and storage on colour stability. J Food Sci Technol 53: 28872894.

Giacomino S, Penas E, Ferreyra V, et al. 2013. Extruded flaxseed meal enhances the nutritional quality of cereal-based products. Plant Foods Hum Nutr 68: 131-136. Doi: 10.1007/s11130-013-0359-8.

Goh KK, Ye A, Dale N. 2006. Characterization of ice cream containing flaxseed oil. Int J Food Sci Technol 41: 946-953. Doi: 10.1111/j.1365-2621.2006.01151.x.

Gokmen V, Mogol BA, Lumaga RB, et al. 2011. Development of functional bread containing nanoencapsulated omega-3 fatty acids. J Food Eng 105: 585-591. Doi: 10.1016/j.jfoo deng.2011.03.021. 
Gopinath B, Harris DC, Flood VM, Burlutsky G, Mitchell P. 2011. Consumption of long-chain n-3 PUFA, a-linolenic acid and fish is associated with the prevalence of chronic kidney disease. $\mathrm{Br} J$ Nutr 105: 1361-1368.

Goyal A, Sharma V, Upadhyay N, et al. 2014. Flax and flaxseed oil: an ancient medicine \& modern functional food. J Food Sci Technol 51: 1633-1653. Doi: 10.1007/s13197-013-1247-9.

Goyal A, Sharma V, Sihag MK, et al. 2016. Fortification of dahi (Indian yoghurt) with omega-3 fatty acids using microencapsulated flaxseed oil microcapsules. J Food Sci Technol 53: 24222433. Doi: 10.1007/s13197-016-2220-1.

Gupta R. 2012. Optimization of Process Variables for the development of flaxseed and defatted flaxseed based pasta. $J$ Nutr Food Sci. Doi: 10.4172/2155-9600.1000172.

Hall C, Tulbek MC, Xu Y. 2006. Flaxseed. Adv Food Nutr Res 51: 1-97.

Hao M, Beta T. 2012. Development of Chinese steamed bread enriched in bioactive compounds from barley hull and flaxseed hull extracts. Food Chem 133: 1320-1325. Doi: 10.1016/j. foodchem.2012.02.008.

Hassan AA, Rasmy NM, Foda MI, Bahgaat WK. 2012. Production of functional biscuits for lowering blood lipids. World J Dairy Food Sci 7: 01-20.

Hussain S, Anjum FM, Butt MS, Alamri, MS, Rafiq Khan M. 2012. Biochemical and nutritional evaluation of unleavened flat breads fortified with healthy flaxseed. Int J Agric Biol 14: 190-196.

Hyvarinen HK, Pihlava J-M., Hiidenhovi JA, et al. 2006. Effect of processing and storage on the stability of flaxseed lignan added to dairy products. J Agric Food Chem 54: 8788-8792. Doi: 10.1021/ jf061285n.

Ivanov S, Rashevskaya T, Makhonina M. 2011. Flaxseed additive application in dairy products production. Procedia Food Sci 1: 275-280. Doi: 10.1016/j.profoo.2011.09.043.

Jain M, Singh C, Gupta K, Jain P. 2014. Formulation and sensory evaluation of healthy heart foods. Nutraceuticals 3: 1-5.

Kajla P, Sharma A. 2016. Nutritional composition of flaxseed varieties. Annals Agri Bio Res 21(1): 75-76.

Kajla P, Sharma A, Sood DR. 2015. Flaxseed-a potential functional food source. J Food Sci Technol 52(4): 1857-1871.

Kapoor S, Sachdeva R, Kochhar A. 2011. Efficacy of flaxseed supplementation on nutrient intake and other lifestyle pattern in menopausal diabetic females. Ethnomedicine 5: 153-160.

Katare C, Saxena S, Agrawal S, Prasad GBKS, Bisen PS. 2012. Flax seed: a potential medicinal food. J Nutr Food Sci 2: 120. Doi: 10.4172/2155-9600.1000120.

Kaur S, Das M. 2014. Nutritional and functional characterization of barley flaxseed based functional dry soup mix. J Food Sci Technol 52: 5510-5521. Doi: 10.1007/s13197-014-1641-y.

Kaur P, Sharma P, Kumar V, Panghal A, Kaur J, Gat Y. 2017. Effect of addition of flaxseed flour on nutritional, physicochemical, phytochemicaland antioxidant properties of cookies. J Saudi Soc Agric Sci, in Press. Available from doi.org/10.1016/j. jssas.2017.12.004.

Khattab R, Zeitoun M, Barbary OM. 2012. Evaluation of pita bread fortified with defatted flaxseed flour. Curr Nutr Food Sci CNF 8: 91-101. Doi: 10.2174/157340112800840790.

Khouryieh H, Aramouni F. 2012. Physical and sensory characteristics of cookies prepared with flaxseed flour. J Sci Food Agric 92: 2366-2372. Doi: 10.1002/jsfa.5642.

Khouryieh H, Aramouni F. 2013. Effect of flaxseed flour incorporation on the physical properties and consumer acceptability of cereal bars. Food Sci Technol Int 19: 549-556. Doi: 10.1177/ 1082013212462231 .
Kristensen M, Jensen MG, Aarestrup J, et al. 2012. Flaxseed dietary fibers lower cholesterol and increase fecal fat excretion, but magnitude of effect depend on food type. Nutr Metab 9: 1-8.

Kristensen M, Savorani F, Christensen S, et al. 2013. Flaxseed dietary fibers suppress postprandial lipemia and appetite sensation in young men. Nutr Metab Cardiovasc 23: 136-143.

Lee RE, Manthey FA, Iii CAH. 2004. Content and stability of hexane extractable lipid at various steps of producing macaroni containing ground flaxseed. J Food Process Preserv 28: 133144. Doi: $10.1111 /$ j.1745-4549.2004.tb00816.x.

Lipilina E, Ganji V. 2009. Incorporation of ground flaxseed into bakery products and its effect on sensory and nutritional characteristics - a pilot study. J Food Serv 20: 52-59. Doi: 10.1111/j.1748-0159.2008.00124.x.

Mani UV, Mani I, Biswas M, Kumar SN. 2011. An open-label study on the effect of flax seed powder (Linum usitatissimum) supplementation in the management of diabetes mellitus. $J$ Diet Suppl 8: 257-265.

Manthey FA, Lee RE, Hall CA. 2002. Processing and cooking effects on lipid content and stability of $\alpha$-linolenic acid in spaghetti containing ground flaxseed. J Agric Food Chem 50: 1668-1671. Doi: $10.1021 / \mathrm{jf} 011147 \mathrm{~s}$.

Manthey FA, Sinha S, Wolf-Hall CE, Hall CA. 2008. Effect of flaxseed flour and packaging on shelf life of refrigerated pasta. J Food Process Preserv 32: 75-87. Doi: 10.1111/ j.1745-4549.2007.00166.x.

Marpalle P, Sonawane SK, Arya SS. 2014. Effect of flaxseed flour addition on physicochemical and sensory properties of functional bread. LWT-Food Sci Technol 58: 614-619.

Masoodi L, Bashir V 2012. Fortification of biscuit with flaxseed: biscuit production and quality evaluation. IOSR J Environ Sci Toxicol Food Technol 1: 06-09. Doi: 10.9790/2402-0150609.

Meethal SM, Kaur N, Singh J, Gat Y. 2017. Effect of Addition of Jackfruit Seed Flour on Nutrimental, Phytochemical and Sensory Properties of Snack Bar. Curr Res Nutr Food Sci J 5: 154-158. Available from doi.org/10.12944/CRNFSJ.5.2.12.

Mentes O, Bakkalbassi E, Ercan R. 2008. Effect of the use of ground flaxseed on quality and chemical composition of bread. Food Sci Technol Int 14: 299-306. Doi: 10.1177/1082013208097192.

Mesquita CDB, Leonel M, Mischan MM. 2013. Effects of processing on physical properties of extruded snacks with blends of sour cassava starch and flaxseed flour. Food Sci Technol (Campinas) 33: 404-410. Doi: 10.1590/s0101-20612013005000073.

Moraes EA, Dantas MIDS, Morais DDC, et al. 2010. Sensory evaluation and nutritional value of cakes prepared with whole flaxseed flour. Food Sci Technol (Campinas) 30: 974-979.

Morris DH. 2007. Flax: A health and nutrition primer. 4th edn. Available from: www.flaxcouncil.ca.

Mridula D, Singh KK, Barnwal P. 2011. Development of omega-3 rich energy bar with flaxseed. J Food Sci Technol 50: 950-957. Doi: 10.1007/s13197-011-0425-x.

Mridula D, Singh KK, Barnwal P. 2013. Development of omega-3 rich energy bar with flaxseed. J Food Sci Technol 50: 950-957.

Ozer BH, Kirmaci HA. 2010. Functional milks and dairy beverages. Int JDairy Technol 63: 1-15. Doi: 10.1111/j.1471-0307.2009.00547.x.

Patil SS, Sheety VS, Todkar AP, Bodhankar HB. 2013. Effect of incorporation of flaxseed flour on the nutritional and sensorial quality of biscuit. Food Sci Res J 4: 20-23.

Rajiv J, Soumya C. 2014. Chemical, rheological and nutritional qualities of sugar snap cookies as influenced by the addition of multigrains. J Food Meas Charact 9: 135-142. Doi: 10.1007/ s11694-014-9218-z. 
Rajiv J, Soumya C. 2015. Chemical, rheological and nutritional qualities of sugar snap cookies as influenced by the addition of multigrains. J Food Meas Charact 9: 135-142.

Rajiv J, Indrani D, Prabhasankar P, Rao GV. 2011. Rheology, fatty acid profile and storage characteristics of cookies as influenced by flax seed (Linum usitatissimum). J Food Sci Technol 49: 587-593. Doi: 10.1007/s13197-011-0307-2.

Ramcharitar A, Badrie N, Mattfeldt-Beman M, et al. 2005. Consumer acceptability of muffins with flaxseed (Linum usitatissimum). J Food Sci. Doi: 10.1111/j.1365-2621.2005.tb11499.x.

Rangrej V, Shah V, Patel J, Ganorkar PM. 2014. Effect of shortening replacement with flaxseed oil on physical, sensory, fatty acid and storage characteristics of cookies. J Food Sci Technol. Doi: 10.1007/s13197-014-1430-7.

Rao PP, Rao GN, Mala KS, et al. 2011. Preparation and storage stability of flaxseed chutney powder, a functional food adjunct. J Food Sci Technol 50: 129-134. Doi: 10.1007/s13197-0110235-1.

Rathi P, Mogra R. 2012. Development and sensory evaluation of superior products with flaxseed. Int J Food Sci Nutri 2: 12-15.

Roozegar MH, Shahedi M, Keramet J, Hamdami N, Roshanak S. 2015. Effect of coated and uncoated ground flaxseed addition on rheological, physical and sensory properties of Taftoon bread. J Food Sci Technol 52: 5102-5110.

Roseling H. 1994. Measuring effects in humans of dietary cyanide exposure to sublethal cyanogens from Cassava in Africa. Acta Hortic 375: 271-283.

Rowan AM, Haggarty NW, Ram S. 2005. Milk bioactives: discovery and proof of concept. Aust J Dairy Technol 60: 114.

Shakeel A, Saeed M, Aslam HKW, et al. 2015. Optimization of colour and cloud stability of carrot juice by using hydrocolloids and antioxidant. J Glob Innov Agric Soc Sci 3: 84-89. Doi: 10.17957/ jgiass/3.2-3.714.

Shanmugam A, Ashokkumar M. 2014. Functional properties of ultrasonically generated flaxseed oil-dairy emulsions. Ultrason Sonochem 21: 1649-1657. Doi: 10.1016/j.ultsonch.2014.03.020.

Shearer AE, Davies CG. 2005. Physicochemical properties of freshly baked and stored whole-wheat muffins with and without flaxseed meal. J Food Qual 28: 137-153. Doi: 10.1111/ j.1745-4557.2005.00004.x.
Singh KK, Mridula D, Rehal J, Barnwal P. 2011. Flaxseed: A potential source of food, feed and fiber. Crit Rev Food Sci Nutr 51: 210 222. Doi: 10.1080/10408390903537241.

Sinha S, Manthey FA. 2008. Semolina and hydration level during extrusion affect quality of fresh pasta containing flaxseed flour. $J$ Food Process Preserv 32: 546-559. Doi: 10.1111/ j.1745-4549.2008.00195.x.

Sudha ML, Begum K, Ramasarma PR. 2010. Nutritional characteristics of linseed/flaxseed (Linum usitatissimum) and its application in muffin making. J Texture Stud 41: 563-578. Doi: 10.1111/ j.1745-4603.2010.00242.x.

Thompson LU, Cunnane SC. 2003. Flaxseed in human nutrition. AOCS Publishing.

Trevisan AJB, Arêas JAG. 2011. Development of corn and flaxseed snacks with high-fibre content using response surface methodology (RSM). Int J Food Sci Nutr 63: 362-367. Doi: 10.3109/ 09637486.2011.629179.

Trevisan AJB, Arêas JAG. 2012. Development of corn and flaxseed snacks with high-fibre content using response surface methodology (RSM). Int J Food Sci Nutr 63: 362-367.

Truan JS, Chen JM, Thompson LU. 2012. Comparative effects of sesame seed lignan and flaxseed lignan in reducing the growth of human breast tumors (MCF-7) at high levels of circulating estrogen in athymic mice. Nutr Cancer 64: 65-71.

United States Department of Agriculture. 2016. https://ndb.nal.usda.gov/ $\mathrm{ndb} /$ foods/show/3716? $\mathrm{manu}=\&$ fgcd= . Accessed 20 April 2016.

Vadukapuram N, Hall C, Tulbek M, Niehaus M. 2014. Physicochemical properties of flaxseed fortified extruded bean snack. International J Food Sci 2014: 1-8. Doi: 10.1155/2014/ 478018.

Wanasundara PKJPD, Amarowicz R, Kara MT, Shahidi F. 1993. Removal of cyanogenic glycosides of flaxseed meal. Food chem 48: 263-266.

Wu W, Huff H, Hsieh F. 2007. Processing and properties of extruded flaxseed-corn puff. J Food Process Preserv 31: 211-226. Doi: 10.1111/j.1745-4549.2007.00105.x.

Yuksel F, Karaman S, Kayacier A. 2014. Enrichment of wheat chips with omega-3 fatty acid by flaxseed addition: Textural and some physicochemical properties. Food Chem 145: 910-917. Doi: 10.1016/j.foodchem.2013.08.079.

Cite this article as: Kaur P, Waghmare R, Kumar V, Rasane P, Kaur S, Gat Y. 2018. Recent advances in utilization of flaxseed as potential source for value addition. OCL 25(3): A304. 